\title{
COVID-19 Vaccines in Pakistan: Efficacy, Adverse Effects and Availability
}

\author{
Soma Siddique ${ }^{1}$, Shaheer Ahmed ${ }^{1}$ \\ ${ }^{1}$ Second year MBBS Student, Islamabad Medical and Dental College, Islamabad, Pakistan
}

\begin{abstract}
A B STRACT
In this review article, we aim to document the efficacy, adverse effects, mode of action, required doses, and availability of the major vaccines available in Pakistan till 20 May 2021. We reviewed all available literature on COVID-19 vaccines in PubMed and Google scholar. We also reviewed articles from grey literature. Currently, Pfizer-BioNTech and Moderna, Sinopharm (China), Sputnik V (Russia), CoronaVac (popularly known as Sinovac) (China), Cansino, and Vaxzevria vaccines have been authorized for emergency use in several countries. Pakistan has sanctioned the use of all the aforementioned vaccines except Pfizer and Moderna. As per their efficacy, Pfizer and Moderna have been found most effective among all the vaccines with $95 \%$ effectiveness, while the Vaxzevria, Sputnik V, Sinopharm, and Cansino have shown 70\%, 91.6\%, $79.34 \%$, and $90 \%$ effectiveness, respectively. All the vaccines have shown milder side effects like headache, fever, and pain on injection sites. To curb the pandemic, more clinical trials are being conducted throughout the world. Importantly public awareness is warranted to achieve the target of vaccinating a large population.
\end{abstract}

Key Words: COVID-19, Vaccination, Efficacy, Thrombosis with Thrombocytopenia Syndrome (TTS), Vaccine Induced Thrombotic Thrombocytopenia (VITT).

\begin{tabular}{lll}
\hline Authors' Contribution: & Correspondence: & Article info: \\
${ }_{1,2}$ Conception; Literature research; manuscript & Soma Siddique & Received: June 1, 2021 \\
design and drafting; Critical analysis and & Email: somamalik562@gmail.com & Accepted: June 16, 2021
\end{tabular}

manuscript review; Data analysis; Manuscript

Accepted: June 16, 2021

Editing

Cite this Review: Siddique S, Ahmed S. COVID-19 Vaccines in Pakistan: Efficacy, Adverse Effects

and Availability. J Islamabad Med Dental Coll. 2021; 10(2): 125-130. Doi:

10.35787/jimdc.v10i2.723

\section{Introduction}

Funding Source: Nil

Conflict of Interest: Nil
The COVID-19 infection caused by severe acute respiratory syndrome coronavirus-2 (SARS-CoV-2) has posed a severe unprecedented social, economic, and healthcare crisis across the globe. It was declared as a pandemic by World Health Organization (WHO), on March 2020 following its spread outside of China. ${ }^{1}$ Being a healthcare challenge itself, it has led to prevalence of other conditions, directly or indirectly as well, such as depression and anxiety endemics, and hindrance to vaccine dissemination and elective surgeries. ${ }^{2-4}$ As of May 2021, about 163,312,429 confirmed cases and 3386,825 associated deaths have been reported worldwide. $^{5}$

To mitigate the global devastation and to curtail this pandemic, the world is in dire need of vaccines. Different organizations are currently working on introducing effective vaccines and a global partnership has been established. In compliance 
with the situation, the development and the testing of vaccines have been accelerated to curb the spread of disease. Currently, a number of SARS-CoV2 vaccines are under clinical $(n=102)$ and pre-clinical $(n=184)$ development throughout the world. ${ }^{6} \mathrm{WHO}$ has approved nineteen vaccines for emergency use. Meanwhile, different countries are approving different vaccines as per their own criteria and feasibility. ${ }^{7}$ South Africa has granted emergency use authorization for six vaccines while Pakistan and UK have authorized five and three major vaccines, respectively. ${ }^{8,9}$

The broad-spectrum definition of vaccine efficacy suggested by FDA includes two important factors. Firstly, the vaccines should have the ability to preclude the transmission of the virus from infected to susceptible person. Secondly, it should be successful in curtailing progression of the diseases along with minimizing the utilization of intensive care resources. ${ }^{10} \mathrm{~A}$ minimum of $50 \%$ efficacy threshold for the vaccine has been determined by the FDA. ${ }^{11}$ Any vaccine above this threshold is allowed to be used for emergencies. One of the studies states that Pfizer and Moderna vaccines have reported $95 \%$ effectiveness following phase III clinical trial, while the efficacy of Vaxzevria (formerly known as AstraZeneca) is claimed to be $70 \%$ in a study by Voysey and colleagues. ${ }^{12,13}$ Another report by Logunov and colleagues affirms $91.6 \%$ effectiveness for the Sputnik V vaccine of Russia. ${ }^{14}$

From the list of these potential vaccines, Pakistan has been able to provide five vaccines, namely: Sinopharm (China), Sputnik V (Russia), Cansino, and the Vaxzevria. ${ }^{9,15}$ This study aims to document the efficacy, advantages, adverse effects, and mode of action and the availability of these major vaccines in Pakistan.

Review of all available literature on the PubMed and Google Scholar was done using following key words and MeSH terms where appropriate: "COVID-19 vaccine", "SARS-CoV-2 vaccine", "Coronavirus Disease 2019 vaccine", "2019-nCoV vaccine" and "2019 Novel Coronavirus vaccine". Grey literature was also seen through different government websites and new published articles. All the available literature published till May 20, 2021 were included in this review.

\section{Pfizer-BioNTech and Moderna:}

Pfizer-BioNTech and Moderna were the first vaccines to get authorization for emergency use in December 2020, and have reported an efficacy of $95 \%$ following the phase III clinical trials. ${ }^{12,16-19}$ Both these vaccines use lipid nanoparticle delivery system or modified mRNA system..$^{20}$ In the latter system, modified mRNA is used to encode the COVID spike proteins, adding mutant mRNA to lock them in a three-dimensional structure which is required to induce an interaction between spike proteins and viral neutralizing antibodies. ${ }^{21}$ These RNA vaccines have a potent effect and can be manufactured rapidly at a very low cost. Since, they are not developed with actual pathogens and are not incorporated into host DNA as is the case with other viral vaccines, they show a better safety profile. However, due to their unstable mRNA, they require extreme refrigeration for storage. Refrigerating temperatures required for Pfizer and Moderna are $60^{\circ} \mathrm{C}$ to $-80^{\circ} \mathrm{C}$ and $-15^{\circ} \mathrm{C}$ to $-25^{\circ} \mathrm{C}$, respectively..$^{22}$ Since ultra-cold temperatures are required for their refrigeration, they are not available in Pakistan. ${ }^{23}$ Both vaccines have shown localized side effects like vomiting, pain, nausea, fever, headache, and muscle aches. In rare cases, these vaccines have also been found to cause anaphylactic reactions. ${ }^{22}$

\section{Vaxzevria:}

The Vaxzevria uses replication-deficient chimpanzee adenovirus inoculating the SARS-CoV-2 proteins in the body to incite immune responses. ${ }^{13}$ After inoculation of the vaccine, body recognizes these 
proteins and begins to develop protective responses that later on preclude the entry of the SARS-CoV-2 virus into the body. ${ }^{24}$ Storage temperature required for ChAdOx1 nCoV-19 vaccine/AZD1222 is $2^{\circ} \mathrm{C}$ to $8^{\circ} \mathrm{C}^{25}$ Several trials for the efficacy of this vaccine were carried out in South Africa and Brazil, which showed an overall efficacy of $70 \% .{ }^{13}$ Milder systematic side effects of diarrhea, fatigue, headache, chills, and nausea have been observed with this vaccine. ${ }^{26}$ Besides these side effects, rare events of thrombosis along with thrombocytopenia, recently termed as thrombosis with thrombocytopenia syndrome (TTS), have also been noticed. ${ }^{27,28}$ However, these thrombotic events have been seen in rare cases even after the administration of millions of doses of the vaccine. ${ }^{29}$ After evaluation of the preliminary data, different international authorities including European Medicines Agency (EMA), the WHO Global Advisory Committee on Vaccine Safety (GVACS), and the UK Medicines and Healthcare products Regulatory Agency (MHRA) have concluded that benefits of vaccine overweighs its risk. ${ }^{30}$ From the initial data available, it has been seen that thrombotic events are reported more in women than men. This finding might be attributed to the use of estrogen containing contraceptives, which are considered one of the risk factors of thrombosis. ${ }^{31}$

\section{Sputnik V:}

Like other vaccines Phase III trials have also been conducted for Sputnik V, which has reported $91.6 \%$ efficacy. ${ }^{14}$ Sputnik $V$ uses an adenovirus vector transport system, much the same as AstraZeneca but it carries two adenovirus vectors Ad5 and Ad26 which aids in expression of gene for spike proteins. ${ }^{32}$ It has been approved for emergency use in 60 countries including China, India, and Pakistan. According to one of the reports, Pakistan has ordered 50,000 doses from Russia. ${ }^{33}$ As per its side effects, mild headache and pain on the injection site are observed. ${ }^{34}$ Furthermore, it is refrigerated at - $18^{\circ} \mathrm{C}$, and two doses are required to be administered at interval of 21 days, as suggested by Ministry of National Health Services, Regulations and Coordination of Pakistan. ${ }^{35}$

\section{Sinopharm:}

The Sinopharm vaccine is the inactivated whole virus vaccine made from vero cells. These cells create multiple copies of the SARS-CoV-2 virus which are then treated with beta-propiolactone, deactivating the virus by binding to its genes. Phase III clinical trials conducted in Argentina, Bahrain, Egypt, Morocco, Pakistan, Peru, and the United Arab Emirates (UAE), have shown $79.34 \%$ efficacy of the vaccine. ${ }^{36}$ Following clinical trials, the vaccine was approved for emergency use in May by WHO. As per the guidance of WHO, two doses of vaccine are required to be administered with 3-4 weeks' interval. ${ }^{37}$ Data available on the side effects of the vaccine shows milder side effects like headache, fever, and pain on injection site, etc. ${ }^{38}$

\section{Cansino-Bio:}

This vaccine is manufactured by CansinoBio Company China. Modified common cold virus is being used as a vector for inoculation of coronavirus genetic material into the human body. It boosts the T cell response, which helps combat the disease. The clinical trials have been conducted in Pakistan, Russia, Mexico and Chile, which have shown 90\% efficacy. Importantly, this vaccine has shown no serious adverse effects. ${ }^{39}$

\section{COVID-19 vaccination in Pakistan (Table I):}

By now, Sinopharm, Cansino-bio, Sinovac (CoronaVac), Sputnik V, and the Oxford UniversityAstraZeneca vaccines have been allowed for emergency use in Pakistan., ${ }^{9,15}$ The vaccination campaign commenced in Pakistan on February 2, $2021 .^{40}$ The initiation of the vaccination campaign in 
Pakistan was marked by donation of vaccines by the Chinese government.

\begin{tabular}{|c|c|c|c|c|c|c|}
\hline \multicolumn{7}{|c|}{ Table I: Summary of major SARS-CoV-2 vaccines } \\
\hline Vaccines & Efficacy & Age limit & $\begin{array}{c}\text { Storage } \\
\text { temperature }\end{array}$ & Doses & $\begin{array}{l}\text { Authorization } \\
\text { in Pakistan }\end{array}$ & Vaccine Manufacturer \\
\hline $\begin{array}{l}\text { Pfizer- } \\
\text { BioNTech }\end{array}$ & $95 \%$ & $\begin{array}{l}16 \text { and } \\
\text { above }\end{array}$ & $-60^{\circ} \mathrm{C}$ to $-80^{\circ} \mathrm{C}$ & $\begin{array}{c}2 \text { shots } \\
21 \text { days apart }\end{array}$ & Not approved & Pfizer-BioNTech \\
\hline Moderna & $95 \%$ & $\begin{array}{l}18 \text { and } \\
\text { above }\end{array}$ & $-15^{\circ} \mathrm{C}$ to $-25^{\circ} \mathrm{C}$ & $\begin{array}{c}2 \text { shots } \\
28 \text { days apart }\end{array}$ & Not approved & $\begin{array}{c}\text { Moderna, } \\
\text { American } \\
\text { pharmaceutical and } \\
\text { biotechnology } \\
\text { company }\end{array}$ \\
\hline Vaxzevria & $70 \%$ & $\begin{array}{l}18 \text { and } \\
\text { above }\end{array}$ & $\begin{array}{l}\text { Regular fridge } \\
\text { temperature }\end{array}$ & $\begin{array}{c}2 \text { shots } \\
21 \text { days apart }\end{array}$ & Approved & $\begin{array}{c}\text { Oxford University and } \\
\text { AstraZeneca }\end{array}$ \\
\hline Sputnik V & $91.6 \%$ & $\begin{array}{l}18 \text { and } \\
\text { above }\end{array}$ & $-18^{\circ} \mathrm{C}$ & $\begin{array}{l}2 \text { shots } \\
21 \text { days apart }\end{array}$ & Approved & $\begin{array}{l}\text { Gamaleya Research } \\
\text { Institute of } \\
\text { Epidemiology and } \\
\text { Microbiology, Russia }\end{array}$ \\
\hline Sinopharm & $79.34 \%$ & $\begin{array}{l}18 \text { and } \\
\text { above }\end{array}$ & $+2^{\circ} \mathrm{C}$ to $+8^{\circ} \mathrm{C}$ & $\begin{array}{c}2 \text { shots } \\
21 \text { days apart }\end{array}$ & Approved & $\begin{array}{c}\text { Sinopharm Group Co., } \\
\text { Ltd, China. }\end{array}$ \\
\hline $\begin{array}{l}\text { Cansino- } \\
\text { bio }\end{array}$ & $90 \%$ & $\begin{array}{l}18 \text { and } \\
\text { above }\end{array}$ & $+2^{\circ} \mathrm{C}$ to $+8^{\circ} \mathrm{C}$ & Single shot & Approved & CanSinoBio \\
\hline
\end{tabular}

However, this vaccination campaign has not gained momentum as only 3 individuals per 100 of the population are currently vaccinated. ${ }^{41}$ To accelerate the vaccination campaign, Pakistan has started purchasing vaccines. One of the reports state that 50,000 doses of Sputnik $V$ vaccine have been imported from Russia and Pakistan is going to receive more doses soon to accelerate underactive vaccination campaign. ${ }^{42}$

\section{Conclusion}

Currently vaccination is the only effective and possible solution to curb this devastating pandemic. For this purpose, collaboration among the researchers and governments have been established throughout the world to put in best efforts to produce effective vaccines. Moreover, clinical trials are being conducted to test the efficacy of these vaccines. About $70-80 \%$ efficacy has been achieved for majority of them. More clinical trials are required to produce effective vaccines and to curtail the spread of the disease completely. It is the government's responsibility to make adequate vaccines available in the country as well as devising a system to monitor its administration and make sure it remains available to its people.

\section{References}

1. Lurie N, Sharfstein JM, Goodman JL. The development of COVID-19 vaccines: safeguards needed. JAMA. 2020; 324 (5): 439-40. Doi:10.1001/jama.2020.12461.

2. Meo SA, Abukhalaf AA, Alomar AA, Sattar K, Klonoff DC. COVID-19 pandemic: impact of quarantine on medical students' mental wellbeing and learning behaviors. Pak J Med Sci. 2020; 36 (COVID19-S4): S43-S48. Doi: 10.12669/pjms.36.COVID19-S4.2809.

3. Ali I. Impact of COVID-19 on vaccination programs: adverse or positive? Hum Vaccines Immunother. 2020; 16(11): 2594-600. Doi: 10.1080/21645515 .2020 .1787065 .

4. lacobucci G. Covid-19: all non-urgent elective surgery is suspended for at least three months in England. BMJ. 2020; 368: m1106. Doi: 10.1136/bmj.m1106. 
5. World Health Organization. WHO Coronavirus (COVID-19) Dashboard 2021, May 1 [Available from: https://covid19.who.int/.

6. WHO. Draft landscape and tracker of COVID-19 candidate vaccines 2021 [Available from: https://www.who.int/publications/m/item/draftlandscape-of-covid-19-candidate-vaccines.

7. WHO. Status of COVID-19 Vaccines within WHO EUL/PQ evaluation process 2021 [Available from: https://extranet.who.int/pqweb/sites/default/files/ documents/Status_COVID_VAX_18May2021.pdf.

8. Menni C, Klaser K, May A, Polidori L, Capdevila J, Louca $P$, et al. Vaccine side-effects and SARS-CoV-2 infection after vaccination in users of the COVID Symptom Study app in the UK: a prospective observational study. Lancet. 2021. Doi: 10.1016/S1473-3099(21)00224-3.

9. Janjua $H$. In Pakistan, COVID-19 vaccines go on sale 18 March 2021 [Available from: https://www.devex.com/news/in-pakistan-covid19-vaccines-go-on-sale-99438].

10. Development and Licensure of Vaccines to Prevent COVID-19 2021. US Food and Drug Administration. [Available from: https://www.fda.gov/regulatoryinformation/search-fda-guidance-

documents/development-and-licensure-vaccinesprevent-covid-19].

11. National Institute of Health. Fourth large-scale COVID-19 vaccine trial begins in the United States September 23, 2020 [Available from: https://www.nih.gov/news-events/news-

releases/fourth-large-scale-covid-19-vaccine-trialbegins-united-states].

12. Polack FP, Thomas SJ, Kitchin N, Absalon J, Gurtman A, Lockhart S, et al. Safety and Efficacy of the BNT162b2 mRNA Covid-19 Vaccine. N Engl J Med. 2020; 383(27): 2603-15. Doi: 10.1056/ NEJMoa2034577.

13. Voysey M, Clemens SAC, Madhi SA, Weckx LY, Folegatti PM, Aley PK, et al. Safety and efficacy of the ChAdOx1 nCoV-19 vaccine (AZD1222) against SARSCoV-2: an interim analysis of four randomised controlled trials in Brazil, South Africa, and the UK. Lancet. 2021; 397(10269): 99-111. Doi: 10.1016/ s0140-6736(20)32661-1.

14. Logunov DY, Dolzhikova IV, Shcheblyakov DV, Tukhvatulin Al, Zubkova OV, Dzharullaeva AS, et al. Safety and efficacy of an rAd26 and rAd5 vectorbased heterologous prime-boost COVID-19 vaccine: an interim analysis of a randomised controlled phase 3 trial in Russia. Lancet. 2021; 397(10275): 671-81. Doi: 10.1016/S0140-6736(21)00234-8.

15. Bhatti MW. DRAP allows emergency authorisation to fifth Covid-19 vaccine April 9, 2021 [Available from: https://www.thenews.com.pk/print/817278-drapallows-emergency-authorisation-to-fifth-covid-19vaccine].

16. Soiza RL, Scicluna C, Thomson EC. Efficacy and safety of COVID-19 vaccines in older people. Age Ageing. 2021; 50(2): 279-83. Doi: 10.1093/ageing/afaa274.

17. Baden LR, El Sahly HM, Essink B, Kotloff K, Frey S, Novak R, et al. Efficacy and Safety of the mRNA-1273 SARS-CoV-2 Vaccine. N Engl J Med. 2020; 384(5): 40316. Doi: 10.1056/NEJMoa2035389.

18. Food, Food DAJ, Administration D. Fact sheet for healthcare providers administering vaccine (vaccination providers): Emergency Use Authorization (EUA) of the Pfizer-BioNTech COVID-19 vaccine to prevent coronavirus disease 2019 (COVID19). Silver Spring, MD: US Department of Health and Human Services. 2021.

19. Mahase E. Covid-19: Moderna vaccine is nearly $95 \%$ effective, trial involving high risk and elderly people shows. BMJ. 2020; 371: m4471. Doi: 10.1136/bmj.m4471.

20. Dolgin E. COVID-19 vaccines poised for launch, but impact on pandemic unclear. Nature. 2020. Doi: 10.1038/d41587-020-00022-y.

21. Walsh EE, Frenck Jr RW, Falsey AR, Kitchin N, Absalon J, Gurtman A, et al. Safety and immunogenicity of two RNA-based Covid-19 vaccine candidates. N Engl J Med. 2020; 383(25): 2439-50. Doi: 10.1056/NEJMoa2027906.

22. Meo S, Bukhari I, Akram J, Meo A, Klonoff DC. COVID19 vaccines: comparison of biological, pharmacological characteristics and adverse effects of Pfizer/BioNTech and Moderna Vaccines. Eur Rev Med Pharmacol Sci. 2021; 25(3): 1663-69. Doi: 10.26355/eurrev_202102_24877.

23. Getting a coronavirus vaccine in Pakistan: What you should know. Geo News. Apr 072021.

24. Knoll MD, Wonodi CJTL. Oxford-AstraZeneca COVID19 vaccine efficacy. Lancet. 2021; 397(10269): 72-4. Doi: 10.1016/S0140-6736(20)32623-4.

25. Cohen J. Vaccine designers take first shots at COVID19. American Association for the Advancement of Science; 2020. Doi: 10.1126/science.368.6486.14.

26. Tsirtsakis A. AstraZeneca and Pfizer: What are the side effects of Australia's vaccines? 03 May 2021 [Available from: https://www1.racgp.org.au/newsgp/clinical/astraze neca-and-pfizer-what-are-the-side-effects-f].

27. 27. Thrombosis with Thrombocytopenia Syndrome (also termed Vaccine-induced Thrombotic Thrombocytopenia). American Society of Hematology. April 29, 2021 [Available from: https://www.hematology.org/covid-19/vaccineinduced-immune-thrombotic-thrombocytopenia]. 
28. James B. Bussel JMC, Douglas B. Cines, Cynthia E. Dunbar, Laura C. Michaelis, Lisa Baumann Kreuziger, Agnes Y. Y. Lee, and Ingrid Pabinger-Fasching. Thrombosis with Thrombocytopenia Syndrome (also termed Vaccine-induced Thrombotic Thrombocytopenia) 2021 [Available from: https://www.hematology.org/covid-19/vaccineinduced-immune-thrombotic-thrombocytopenia].

29. Masten A. ISTH Statement on Astrazeneca Covid-19 vaccine and thrombosis. March 12, 2021.

30. Benefits of COVID-19 Vaccine AstraZeneca outweigh risks of blood clots. Reactions Weekly. 2021; 1848(1): 2. Doi: 10.1007/s40278-021-93004-3.

31. Lancet Haematology. COVID-19 vaccines: building and maintaining confidence. Lancet (Editorial). 2021; 8(5): E305. Doi: 10.1016/S2352-3026(21)00107-1.

32. Logunov DY, Dolzhikova IV, Zubkova OV, Tukhvatullin Al, Shcheblyakov DV, Dzharullaeva AS, et al. Safety and immunogenicity of an rAd26 and rAd5 vectorbased heterologous prime-boost COVID-19 vaccine in two formulations: two open, non-randomised phase 1/2 studies from Russia. Lancet. 2020; 396(10255): 887-97. Doi: 10.1016/S0140-6736(20)31866-3.

33. Statista. Number of Doses of COVID-19 vaccines Sputnik V ordered from Russia. 2021 [Available from: https://www.statista.com/statistics/1123927/sputni k-v-exports-from-russia-by-country/].

34. Gulland A. Sputnik vaccine: side effects, efficacy - and is the Russian Covid jab safe? The Telegraph. 1 April 2021.

35. Government of Pakistan MoNHS, Regulation and coordination. COVID-19 Vaccination Updated Sputnik V Vaccine Guidelines. 03 May 2021.
36. Jajja S. All you need to know about Covid vaccines in Pakistan. DAWN NEWS. 2021.

37. WHO Strategic Advisory Group of Experts (SAGE) on Immunization. The Sinopharm COVID-19 vaccine: What you need to know 2021 [Available from: https://www.who.int/news-room/featurestories/detail/the-sinopharm-covid-19-vaccinewhat-you-need-to-know.

38. Pik H. Sinopharm COVID-19 vaccine: Should you worry about the side effects? 2021 [Available from: https://www.medicalnewstoday.com/articles/sinop harm-covid-19-vaccine-should-you-worry-aboutthe-side-effects.

39. Ramasamy MN, Minassian AM, Ewer KJ, Flaxman AL, Folegatti PM, Owens DR, et al. Safety and immunogenicity of ChAdOx1 nCoV-19 vaccine administered in a prime-boost regimen in young and old adults (COV002): a single-blind, randomised, controlled, phase 2/3 trial. Lancet. 2020; 396(10267): 1979-93. Doi: 10.1016/S0140-6736(20)32466-1.

40. Standard B. Pakistan to buy $7 \mathrm{mn}$ doses of coronavirus vaccines from China: Minister 2021 [Available from: https://www.businessstandard.com/article/current-affairs/pakistan-tobuy-7-mn-doses-of-coronavirus-vaccines-fromchina-minister-121032600569_1.html.

41. Hashim A. Pakistan receives another large COVID vaccine shipment from China. ALJAZEERA. $1 \mathrm{Apr}$ 2021.

42. NEWS IT. Corona vaccine available for all age groups 2021 [Available from: https://www.thenews.com.pk/print/814174corona-vaccine-available-for-all-age-groups.]. 